\title{
Treatment of Dairy Processing Wastewater using Integrated Submerged Membrane Microfiltration System
}

\author{
Al-Shammari SB ${ }^{1 *}$, Bou-Hamad S $^{2}$, Al-Saffar A $^{2}$, Salman $\mathbf{M}^{2}$ and Al-Sairafi A $^{2}$ \\ ${ }^{1}$ Environmental Health Departments, College of Health Science, The Public Authority for Applied Education and Training, P. O. Box 14281, Faiha 72853, Kuwait \\ ${ }^{2}$ Kuwait Institute for Scientific Research, Water Technologies Department, P.O. Box 24885, Safat 13109, Kuwait
}

\begin{abstract}
Dairy wastewater effluent has become one of the major concerns for the dairy processing industries. Because of large of wastewater effluent generation, the dairy processing industries may become potential candidates for wastewater reuse. Treated wastewater can be utilized in cooling systems and washing plant floor, as well its potential use for greenery irrigation purposes. In addition, treating dairy effluent will also benefit the environment. The purpose of this study is to characterize wastewater from a selected dairy industry in Kuwait (KD Cow Company) and a study of applying microfiltration treatment process for treating the dairy wastewater. A complete treatment system including biological treatment, powdered activated carbon (PAC) and submerged membrane microfiltration system (CMF-S) was installed at Kuwait Institute for Scientific Research (KISR) research plant. The overall results of this study indicate that the complete system is capable of treating the dairy effluent. The average removal efficiencies of the system for biological oxygen demand (BOD), chemical oxygen demand (COD), total dissolved solid (TDS) were $98.8 \%, 92.5 \%, 96.7 \%$ respectively.
\end{abstract}

Keywords: Wastewater; Treatment; Dairy; Membrane

\section{Introduction}

In Kuwait dairy industries are located in the Sulaibiya agricultural farm area with no access to the municipal system. The site is under the monitoring by the Environmental Public Authority (EPA), hence, the waste effluent is transported by sewage tankers to the disposal sites in distant parts of the desert. Consequently, disposing untreated dairy wastewater can lead to adverse public health and environmental impacts. Examples of environmental concerns include objectionable odors and fly infestations that have resulted from the disposal of the untreated effluent in open land. Among the food industries, the dairy industry characteristically requires very large quantities of freshwater and generates large quantites of wastewater. Most of the wastewater volume generated in the dairy industry results from cleaning of transport lines and equipment between production cycles, cleaning of tank trucks, washing of milk silos and equipment malfunctions or operational errors [1-3].

Although the dairy processing industry does not usually deal with extremely hazardous materials, there are many contaminants found in the waste streams that are potentially harmful to the environment. This is particularly true for dairy wastewater which has high concentration of nutrients (nitrate, sulfate and phosphate) along with relatively high BOD, COD and total suspended solid (TSS) [4]. These make the dairy waste unsuitable to be discharged to sewer system or seawater. Recently, the enforcement of environmental legislations is becoming a high priority for the state of Kuwait. Dairy industrial sectors have to comply with the Kuwait Environment Public Authority (KEPA) regulations for wastewater discharge and reuse [5]. To satisfy these regulations the effluent must be collected and treated to meet the quality standards set by KEPA.

\section{Dairy wastewater treatment}

Wastewater treatment systems are designed to eliminate or reduce contaminants to satisfy discharge regulations. There are many methods for treating wastewater generated in dairy industries. Physico-chemical and biological treatment methods are usually used to treat dairy wastewater effluent $[2,3,6]$. However, several studies have found that COD removal is poor in physical-chemical treatment processes and the costs of chemical coagulaents are high [7]. On ther hand better organics removal and good effluent quality were reported using biological processes [8]. Among biological treatment processes, treatment in ponds, activated sludge plants and anaerobic treatment are commonly employed for dairy wastewater [9]. In recent years several works focused on the treatment of dairy effluents demonstrated that application of membrane technologies such as microfiltration (MF), ultrafiltration (UF), nanofiltration (NF) and reverse osmosis (RO) were becoming more energy efficient as compared to conventional methods. [10-13].

Membrane technology is based on the principle of selective permeability of one or more components of a liquid mixture through a membrane barrier [14]. In an evaluation of various treatment options for reducing the chemical oxygen demand (COD) of effluents from slaughter house, UF and reverse osmosis processes were more economical than more traditional methods of effluent treatment such as aerobic and anaerobic fermentation and coagulation [15]. The works, that have been dedicated to the treatment of the so-called process waters (flushing waters, first rinse waters or "white waters"), show that nanofiltration (NF) or reverse osmosis (RO) is adequate for the concentration of milk components existed in wastewater stream. The results showed that one single membrane operation allowed the milk constituents to be concentrated in the retentate but reusable water of composition complying with the standard of purified water

*Corresponding author: Al-Shammari SB, Environmental Health Departments, College of Health Science, The Public Authority for Applied Education and Training, P. O. Box 14281, Faiha 72853- Kuwait, Tel: 965-99668017; E-mail: s.b.alwan@gmail.com, salalwan@gmail.com

Received December 14, 2015; Accepted February 22, 2015; Published February 26, 2015

Citation: Al-Shammari SB, Bou-Hamad S, Al-Saffar A, Salman M, Al-Sairafi A (2015) Treatment of Dairy Processing Wastewater using Integrated Submerged Membrane Microfiltration System. J Environ Anal Toxicol 5: 278. doi: 10.4172/2161-0525.1000278

Copyright: () 2015 Al-Shammari SB, et al. This is an open-access article distributed under the terms of the Creative Commons Attribution License, which permits unrestricted use, distribution, and reproduction in any medium, provided the original author and source are credited. 
from process water was not reached. Integrating two processes such as biological treatment including aeration tank, settling tank and powdered activated charcoal (PAC) with advanced membrane filtration, may yield to a better filtration quality. In this work the integrated system was used to treat effluent from KD Cow dairy processing plant at Sulaibiya area.

\section{Material and Methods}

The complete system for wastewater treatment involves the integration of membrane separation and conventional biological treatment processes. The membrane separation process includes the CMF-S system which is, a fine filtration process which is a polypropylene membrane filter to remove particles greater than $0.2 \mu \mathrm{m}$ in size from a feed stream. The MEMCOR ${ }^{\oplus}$ CMF-S process utilizes hollow fiber membranes to provide a self-cleaning system that can maintain high flow rates by the use of a combined air scour and liquid backwash cycle. The membranes are assembled to form a sub-module. This integrated system is shown in (Figure 1), in which feed water passes through an aeration tank for biological treatment. An air compressor injects an adequate air into the aeration tank. The aerobic system includes the process air blowers which are installed adjacent to the system. The required process air flow is $227 \mathrm{~m}^{3} / \mathrm{h}$ introduced at the bottom of the aerobic tank through air scour distribution header pipes. After passing through the upstream flow, the mixed liquor is transferred by overflow to a suitable buffer flow tank and then pressurized to an operating pressure in accordance with the membrane's design. The specifications of these membrane modules as the following:

1. Number of modules: 4

2. Membrane types: Polypropylene

3. Membrane area: $13 \mathrm{~m}^{2}$ each

4. Filtration direction: outside in

5. Fiber outside diameter: $650 \mu \mathrm{m}+30 \mu \mathrm{m}$
6. Fiber inside diameter: $390 \mu \mathrm{m}+20 \mu \mathrm{m}$

7. Number of fiber: 14,500 nominal

The treated effluents will flow through PAC to suppress any lactose in the feed effluent and to reduce any odor in the feed water. In the filtration cycle, the membrane tank is filled with feed water to just above the tops of the sub-modules; the inside (filtrate side) of the membranes are then placed under the suction head of the filtrate pump. Filtration takes place from the outer surface of the fiber to the hollow inner core. Feed liquid passes through the porous wall of the fibers, and suspended matter remains on the feed side. This filtration process removes solids larger than approximately $0.2 \mu \mathrm{m}$. As a guide, bacteria are typically larger than about $1 \mu \mathrm{m}$. As deposits build up on the fibers, filtration flow resistance increases, resulting in a drop in filtration flow rate. To reduce the flow resistance and restore the filtration flow rate, the membrane is backwashed. During backwash, filtration is stopped and air is applied to the outside of the fibers. A small amount of filtrate is pushed through the fibers (from inside to out) to further remove deposits from the outer surface of the fibers. The tank is then drained to transport any dislodged deposits to the clarifier tank for the separation of any solid particles. The sludge will settle at the bottom of the clarifier. The overflow from the clarifier will be recycled to the aeration tank for further treatment to prevent fermentation of the backwash water.

\section{Analytical method}

All parameter determinations in the laboratory were performed according to outlined Standard Methods for Water and Wastwater. Both chemical and biological analyses were carried out at the laboratories of KISR Sulaibiya Wastewater Research Plant. Furthermore, the analysis results were cross checked randomly with KISR Central Analytical Laboratory $(\mathrm{CAL})$ as quality assurance.

\section{Results and Discussion}

\section{Sampling and field measurements}

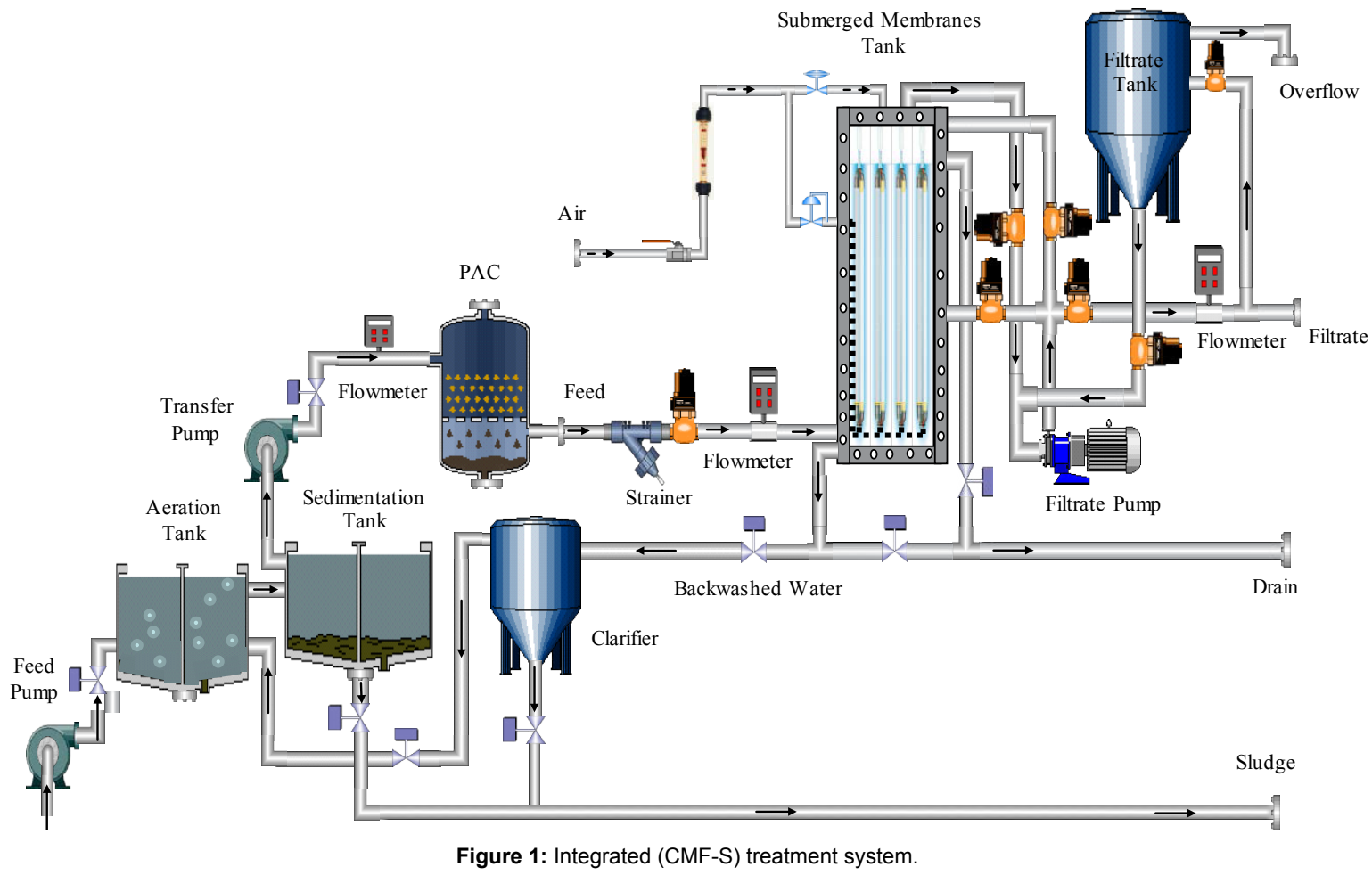


Citation: Al-Shammari SB, Bou-Hamad S, Al-Saffar A, Salman M, Al-Sairafi A (2015) Treatment of Dairy Processing Wastewater using Integrated Submerged Membrane Microfiltration System. J Environ Anal Toxicol 5: 278. doi:10.4172/2161-0525.1000278

Page 3 of 6

Wastewater within KD Cow dairy processing plant was sampled and monitored on a weekly basis. The samples were collected at points of wastewater outfalls and storage tanks. The type of effluent used in this treatment technique is characterized as dairy industrial wastewater. Dairy refers to a processing plant in which milk or milkbased products are processed into a variety of dairy foods such as milk, cheese, ice cream, sour cream, cream, butter, etc. It does not include operations in which milk cows are raised and/or milked. Wastewater is primarily washwater resulting from cleaning and sanitizing equipment; thus, it contains some dairy product. Water from general cleanup and hosing down plant facilities ends up in the drains as does rejected fluid from the cleaning in-place (CIP) operations. In addition, product spills of various kinds frequently end up in the floor drains and therefore, become part of the wastewater. The average wastewater generated from $\mathrm{KD}$ Cows dairy processing plant is $25.24 \mathrm{~m}^{3} / \mathrm{h}$ which is drained to a waste pit then collected by a wastewater tanker. Table 1 presents the physical and chemical characteristics of the KD Cow effluent, whereas (Table 2) present biological the characteristics of the KD Cow effluent. Table 1 shows the fluctuation in the $\mathrm{pH}$ values from 9.64 to 11.25 , this is due to the use of CIP in the plant where some detergent or disinfectant has been used. The organic pollutant content of this dairy effluent is commonly expressed as the $\mathrm{BOD}_{5}$ and COD. As seen on (Table 2) the concentrations of $\mathrm{BOD}$ and $\mathrm{COD}$ in the dairy processing effluents vary widely, from 80 to $246(\mathrm{mg} / \mathrm{l})$ and 216 to $431(\mathrm{mg} / \mathrm{l})$, respectively.

\section{Operating and optimizing the pilot unit}

During the period of this task, the integrated treatment system was operated and tested on a daily basis and operating parameters, such as $\mathrm{pH}$, temperature, feed pressure, flow rate, feed conductivity and turbidity, were monitored and recorded daily. The graphical presentations of the data recorded daily for the turbidity and transmembrane pressure (TMP) appear in (Figure 2,3). The temperature of the feedwater to the system ranged between 24.90 and $41.30^{\circ} \mathrm{C}$, during winter and summer respectively, as shown in (Figure 4). The $\mathrm{pH}$ of the feedwater during this period was between 6.06 and 12.17 as shown in (Figure 5) Feed and filtrate turbidity values ranged from 6.59 to 429 NTU and from 0.09 to $17.42 \mathrm{NTU}$, respectively, as shown in (Figure 3). The turbidity measuring unit is Nephelometric Turbidity Unit (NTU) as recommended by the filter manufacturer. The conductivity of the feed water was also monitored and was found to be between 79.9 and $3,610 \mu \mathrm{S} / \mathrm{cm}$ during the monitoring period as presented in (Figure 6). The conductivity measuring unit is Micro Siemens per $\mathrm{cm}(\mu \mathrm{S} / \mathrm{cm})$ as recommended by the membrane manufactures. At the beginning of the experimental testing program the pilot system was tested under variable operating conditions to determine the optimal operating conditions of the system.

During commissioning period, operating parameters were optimized to achieve best performance of the biological treatment system. The optimized parameters were flowrate, HRT, SRT, dissolved oxygen (DO) and MLSS. The biological treatment system was operated with aerobic (capacity $6 \mathrm{~m}^{3}$ ) and anoxic (capacity $6 \mathrm{~m}^{3}$ ) tanks, and with a flux range of 14 to $24 \mathrm{l} / \mathrm{m}^{2} / \mathrm{h}$ and an HRT of $2 \mathrm{~h}$. The system was operated without activated sludge wasting to allow the MLSS to increase in the aeration tank. The sludge wasting rate was set to give an SRT in the range of 34 to $47 \mathrm{~h}$. The average TSS recorded in the aeration tank was $120 \mathrm{mg} / 1$, with maximum and minimum values of 274 and 10 $\mathrm{mg} / 1$, respectively. The SRT values are presented in (Figure 7). The DO concentrations in the biological treatment ranged from 2.0 to $2.7 \mathrm{mg} / \mathrm{l}$ and from 0.1 to $0.7 \mathrm{mg} / \mathrm{l}$, in the aerobic and anoxic tanks, respectively (Figure 8). It is worth mentioning that during the operation there were negligible amount of sludge and surface foam recovered from the settling tank compared to the amounts of flowrate to the system.

\section{Quality analysis}

The results of all analyses are summarized in (Table 3 ) represents the chemical analysis of maximum, minimum and average of raw water, feed water, and filtrate water. While (Table 3) presents the removal efficiencies of the integrated treatment system in reducing the BOD, COD, and TSS. Figure 9-11 show graphic presentation of the performance for the system in term of the reduction of values of COD, BOD and TSS, respectively. Chemical analyses of all samples indicate that the integrated treatment system had no significant effect on other constituents of the dairy effluent wastewater such as phosphate, $\mathrm{Mg}^{+}$, $\mathrm{Ca}^{+}$and EC. The analysis showed that the integrated treatment system

\begin{tabular}{|c|c|c|c|}
\hline Parameters & Average & Max & Min \\
\hline Total dissolved solid (TDS) mg/l & 997.2 & 1075 & 944 \\
\hline Electrical conductivity $\mu \mathrm{s} / \mathrm{cm}$ & 1356.6 & 1605 & 1072 \\
\hline $\mathrm{pH}$ & 10.072 & 11.25 & 9.64 \\
\hline Total Alkalinity (mg/l as $\mathrm{CaCO}_{3}$ ) & 186.3 & 199 & 173 \\
\hline $\mathrm{Ca}^{+} \mathrm{mg} / \mathrm{l}$ as $\mathrm{CaCO}_{3}$ & 14.475 & 16.2 & 13.8 \\
\hline $\mathrm{Mg}^{+}(\mathrm{mg} / \mathrm{l})$ & 5.737 & 6.3 & 4.98 \\
\hline $\mathrm{SO}_{4}^{-}(\mathrm{mg} / \mathrm{l})$ & 124.25 & 162 & 113 \\
\hline $\mathrm{Cl}^{-}(\mathrm{mg} / \mathrm{l})$ & 377.4 & 382.15 & 370.67 \\
\hline Turbidity (NTU) & 233.5 & 475 & 82 \\
\hline $\begin{array}{l}\text { Total suspended solid (TSS) } \\
\text { (mg/l) }\end{array}$ & 99.25 & 131 & 65 \\
\hline $\mathrm{NH}_{3}-\mathrm{N}(\mathrm{mg} / \mathrm{l})$ & 2.3755 & 2.91 & 1.01 \\
\hline $\mathrm{NO}_{3}^{-} \mathrm{mg} / \mathrm{l}$ & 79.30 & 87.1 & 51.62 \\
\hline $\mathrm{PO}_{4}^{-}(\mathrm{mg} / \mathrm{l})$ & 6.5125 & 7.87 & 5.02 \\
\hline
\end{tabular}

The presented values represent a total of 20 samples.

Table 1: Physical and Chemical Characteristics of the KD Cow Effluent.

\begin{tabular}{|c|c|c|c|}
\hline Parameter & Average & Max & Min \\
\hline Bio-Chemical Oxygen Demand $\left(\mathrm{BOD}_{5}\right)(\mathrm{mg} / \mathrm{l})$ & 160.05 & 246 & 80 \\
\hline Chemical Oxygen Demand $(\mathrm{COD})(\mathrm{mg} / \mathrm{l})$ & 257.7 & 431 & 216 \\
\hline Fecal Coliform Bacteria (coloni / 100 ml) & & 0 & 0 \\
\hline Oil \& Grease (ppm) & 26.13 & 56.81 & 2.57 \\
\hline
\end{tabular}

'The presented values represent a total of 20 samples

Table 2: Biological Characteristics of the KD Cow Effluent.

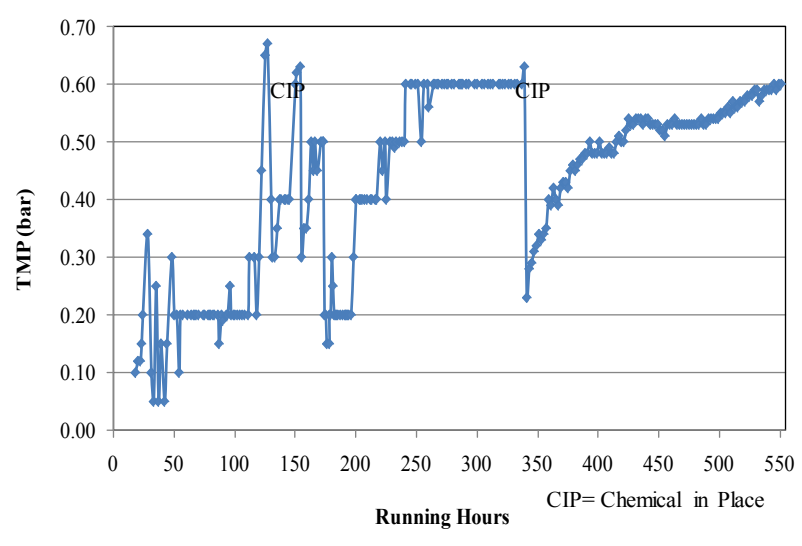

Figure 2: Transmembrane pressure (TMP) versus running hours. 
Citation: Al-Shammari SB, Bou-Hamad S, Al-Saffar A, Salman M, Al-Sairafi A (2015) Treatment of Dairy Processing Wastewater using Integrated Submerged Membrane Microfiltration System. J Environ Anal Toxicol 5: 278. doi:10.4172/2161-0525.1000278

Page 4 of 6

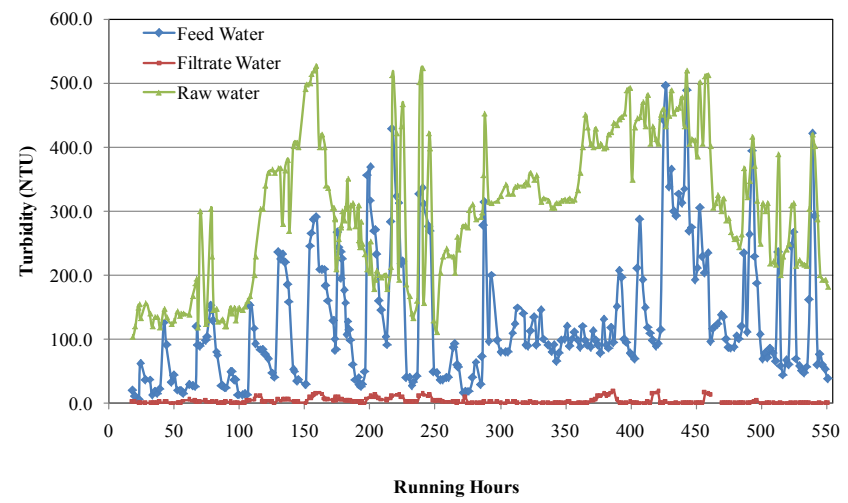

Figure 3: Raw, Feed and filtrate turbidity versus running hours.

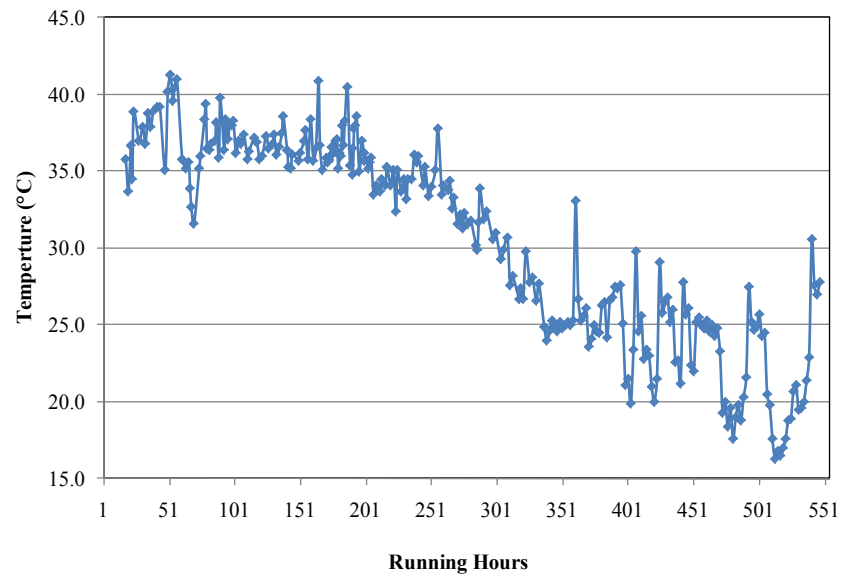

Figure 4: Raw wastewater temperature versus running hours.

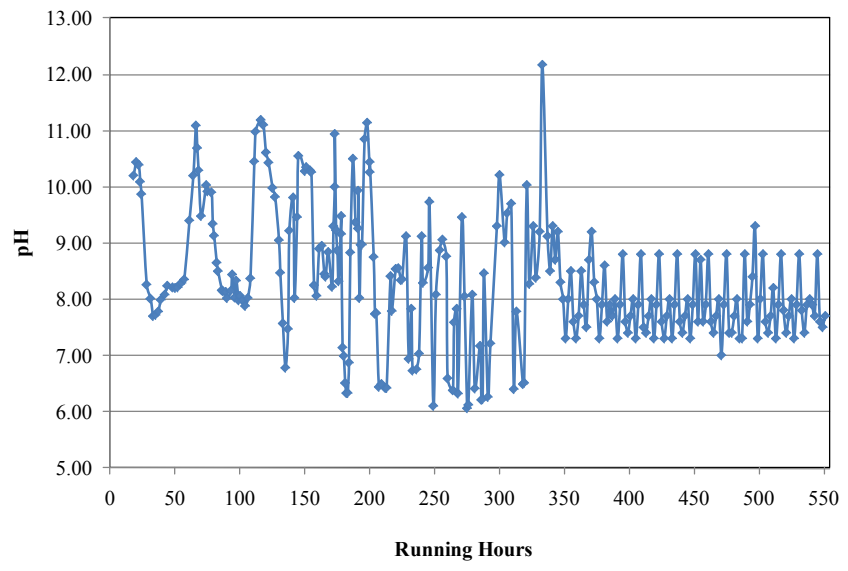

Figure 5: Raw water $\mathrm{pH}$ versus running hours.

can reduce BOD by up to 98.8 , COD by up to $92.5 \%$ and TSS by up to $96.7 \%$ as can be seen in (Table 4 ). This reflects the excellent efficiency of both the CMF-S and the biological treatment including the aeration tank and the activated carbon filter in removing biological matter and suspended materials from the dairy effluent wastewater.

\section{COD and BOD}

The COD and BOD measurements of feedwater and integrated
(CMF-S) treatment system filtrate are shown in (Figure 9,10) respectively. The influent COD and BOD was highly fluctuating during the period of operation and was in the range of from $26-1237 \mathrm{mg} / \mathrm{l}$ and $569-1208 \mathrm{mg} / \mathrm{l}$, respectively. COD concentration in the effluent was varied from 1.3-36 mg/l with an average value of $9 \mathrm{mg} / \mathrm{l}$. whereas the majority of BOD values of the integrated system filtrate were less than $8 \mathrm{mg} / \mathrm{l}$, with an average value of $3.2 \mathrm{mg} / \mathrm{l}$. Table 4 presents removal efficiencies for BOD, COD and TSS. The average removal efficiencies of the system for BOD, chemical oxygen demand COD were $98.8 \%$ and $92.5 \%$, respectively. This significant reductions in both COD and BOD values revealed that the heterotrophic bacteria which is responsible of

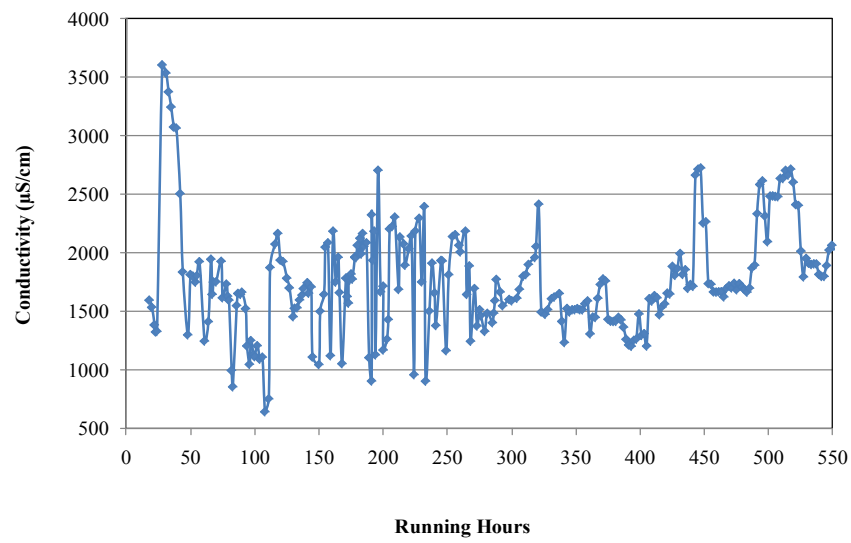

Figure 6: Feedwater conductivity versus running hours.

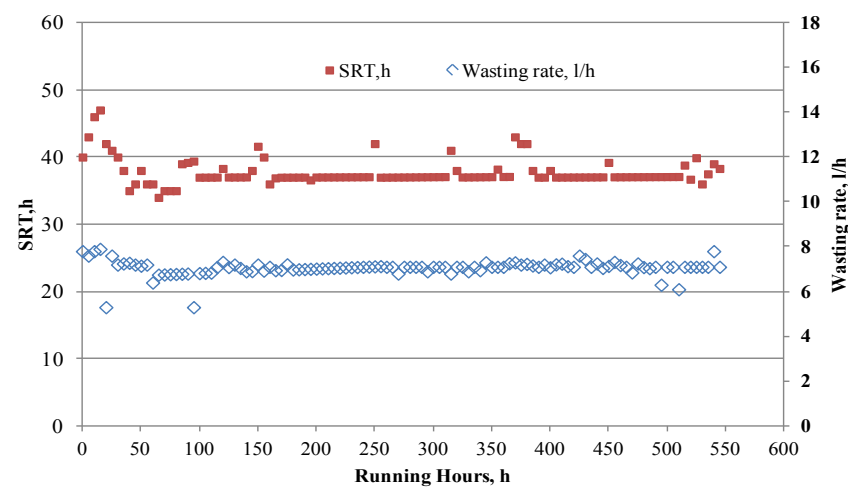

Figure 7: Solid retention time of the biological treatment.

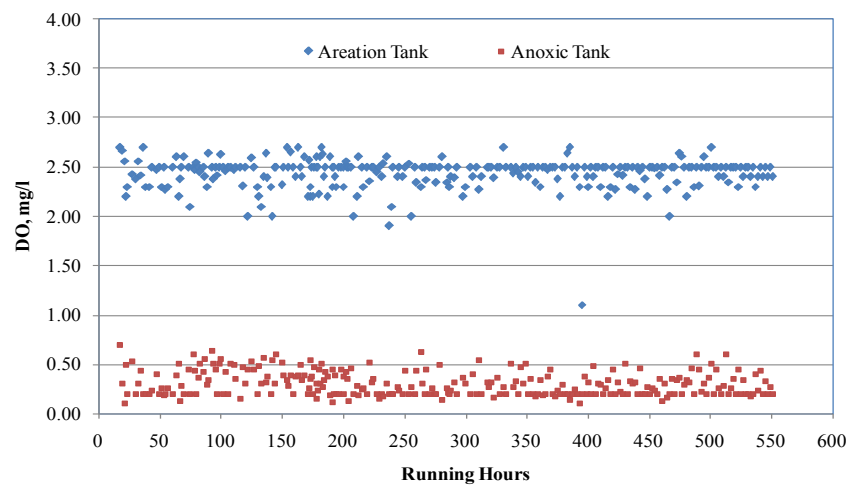

Figure 8: Dissolve oxygen versus running hours for aeration and anoxic tanks. 
Citation: Al-Shammari SB, Bou-Hamad S, Al-Saffar A, Salman M, Al-Sairafi A (2015) Treatment of Dairy Processing Wastewater using Integrated Submerged Membrane Microfiltration System. J Environ Anal Toxicol 5: 278. doi:10.4172/2161-0525.1000278

Page 5 of 6

\begin{tabular}{|c|c|c|c|c|c|c|c|c|c|}
\hline \multirow{2}{*}{ Parameters } & \multicolumn{3}{|c|}{ Raw Water } & \multicolumn{3}{|c|}{ Feed Water } & \multicolumn{3}{|c|}{ Filtrate Water } \\
\hline & Max & Min & Ave & Max & Min & Ave & Max & $\min$ & Ave \\
\hline $\mathrm{pH}$ & 12.35 & 6.10 & 10.38 & 11.80 & 6.85 & 8.86 & 11.73 & 7.08 & 8.73 \\
\hline $\mathrm{EC}(\mu \mathrm{S} / \mathrm{cm})$ & 3940.00 & 693.00 & 2029.22 & 3580.00 & 864.00 & 1841.11 & 2570.00 & 782.00 & 1667.67 \\
\hline TSS (mg/l) & 638.00 & 21.00 & 281.00 & 274.00 & 10.00 & 128.00 & 35.20 & 1.00 & 9.00 \\
\hline Turbidity (NTU) & 527 & 103 & 300.8 & 496 & 6.6 & 128.7 & 18 & 0.04 & 3.3 \\
\hline TDS (mg/l) & 2276.00 & 564.00 & 1419.00 & 3118.00 & 639.00 & 1315.54 & 1956.00 & 614.00 & 1187.47 \\
\hline $\mathrm{Cl}^{-}(\mathrm{mg} / \mathrm{l})$ & 269.00 & 70.00 & 120.62 & 295.00 & 60.00 & 151.92 & 285.00 & 40.00 & 138.27 \\
\hline Total Alkalinity (mg/l) & 972.00 & 66.00 & 457.14 & 1554.00 & 206.00 & 602.81 & 1220.00 & 156.00 & 579.47 \\
\hline $\mathrm{PO}_{4}^{-}(\mathrm{mg} / \mathrm{l})$ & 22.52 & 2.76 & 9.71 & 17.39 & 2.09 & 6.34 & 6.98 & 1.53 & 3.54 \\
\hline $\mathrm{Ca}^{+}(\mathrm{mg} / \mathrm{l})$ & 0.53 & 0.01 & 0.18 & 0.39 & 0.01 & 0.10 & 0.07 & 0.00 & 0.03 \\
\hline $\mathrm{Mg}^{+}(\mathrm{mg} / \mathrm{l})$ & 2.45 & 1.54 & 1.91 & 2.33 & 0.47 & 1.41 & 1.90 & 0.28 & 1.12 \\
\hline $\mathrm{Pb}^{+}(\mathrm{mg} / \mathrm{l})$ & 0.00 & 0.00 & 0.00 & 0.00 & 0.00 & 0.00 & 0.00 & 0.00 & 0.00 \\
\hline $\mathrm{Cd}^{+}(\mathrm{mg} / \mathrm{l})$ & 0.43 & 0.01 & 0.08 & 0.04 & 0.00 & 0.02 & 0.04 & 0.00 & 0.02 \\
\hline $\mathrm{Zn}^{+}(\mathrm{mg} / \mathrm{l})$ & 0.44 & 0.05 & 0.14 & 0.13 & 0.02 & 0.06 & 0.06 & 0.00 & 0.02 \\
\hline $\mathrm{Ni}^{+}(\mathrm{mg} / \mathrm{l})$ & 0.02 & 0.00 & 0.01 & 0.01 & 0.00 & 0.01 & 0.01 & 0.00 & 0.00 \\
\hline
\end{tabular}

*The presented values represent a total of 115 samples.

Table 3: Chemical Analysis of Raw Water, Feed Water and Filtrate Water.

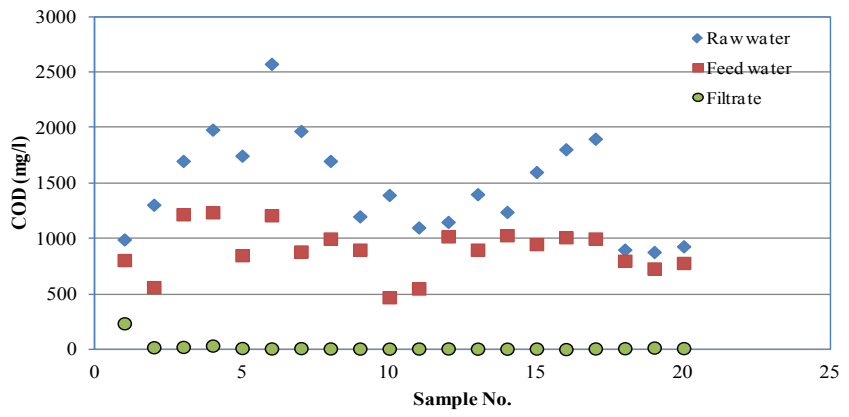

Figure 9: COD measurements of raw, feed water and filtrate.

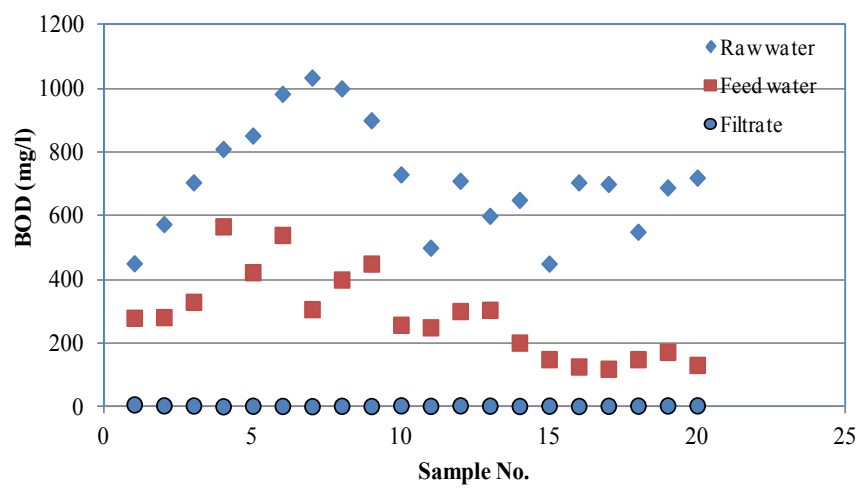

Figure 10: BOD measurements of raw, feed water and filtrate.

degrading the carbonaceous organic were rich in aerobic zone of the system. These results also, show that the integrated system can provide consistently high organic removal efficiency during continuous long time of operation.

\section{Conclusion}

Based on the results of this study, the following conclusions were made:

- The performance of the integrated treatment system is capable of treating the dairy wastewater effluent and producing good filtrate water with an average turbidity of 3.3 NTU clear of most

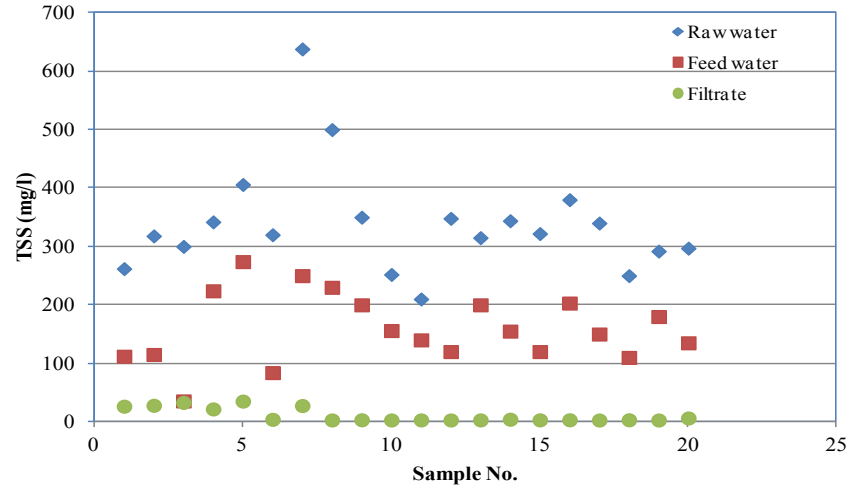

Figure 11: TSS measurements of raw, feed water and filtrate.

\begin{tabular}{|c|c|}
\hline Parameters & Removal Efficiency (\%) \\
\hline TSS & 96.7 \\
\hline COD $(\mathrm{mg} / \mathrm{l})$ & 92.5 \\
\hline BOD $(\mathrm{mg} / \mathrm{l})$ & 98.8 \\
\hline
\end{tabular}

Table 4: Average Removal Efficiencies of the Integrated Treatment System.

impurities.

- $\quad$ The average removal efficiencies of the integrated treatment system for, BOD, COD and TSS were $98.8 \%, 92.5 \%$ and $96.7 \%$, respectively.

- The chemical analysis revealed that both biological and CMF-S systems can significantly improved the quality of dairy wastewater effluents. Therefore, water produced from the both systems could be considered to be safe for agriculture, industry and other indirect human use.

- $\quad$ The final filtrate of the system is suitable for further polishing with RO system for a further improved water quality.

- $\quad$ The system demonstrates an excellent operational availability under prevalent conditions of Kuwait which was $90.39 \%$.

- The characteristics of water produced from the integrated 
Citation: Al-Shammari SB, Bou-Hamad S, Al-Saffar A, Salman M, Al-Sairafi A (2015) Treatment of Dairy Processing Wastewater using Integrated Submerged Membrane Microfiltration System. J Environ Anal Toxicol 5: 278. doi:10.4172/2161-0525.1000278

system were better than the standard for water reusing in landscaping.

\section{Aknowledgements}

The authors would like to express their gratitude to the Kuwait Foundation for the Advancement of Sciences for the partial funding of the project and to Kuwait Dairy Company (KD Cow) for their cooperation in implementing this project.

\section{References}

1. Baskaran K, Palmowski LM, Watson B M (2003) Wastewater reuse and treatment options for the dairy industry. Water Science and Technology 3: 8591.

2. Danalewich JR, Papagiannis TG, Belyea RL, Tumbleson, Raskin MEL (1998) Characterization of dairy waste streams, current treatment practices, and potential for Biological nutrient removal. Water Research 32: 3555-3568.

3. Vidal G, Carvalho A, Mendez R, Lema JM (2000) Influence of the content in fats and Proteins on the anaerobic biodegradability of dairy wastewaters. Bioresource Technology 74: 231-239.

4. Green M, Gidron E, Beliavski M, Lahav O, Tarre S (2004) Treatment of Dairy Wastewater using a Vertical Bed with Passive Aeration. Environmental Technology 25: 1123-1130.

5. Environmental Public Authority Kuwait (EPA) (2001) Wastewater criteria for disposal.

6. Kasapgil B, Anderson GK, Ince O (1994) An investigation into the pretreatment of dairy wastewater prior to aerobic biological treatment. Water Science Technology 29: 205-212.
7. Sharma D (2014) Treatment of dairy waste water by electro coagulation using aluminum electrodes and settling, filtration studies. International Journal of Chemical Technolgy Research 6: 591-599.

8. Bangsbo D, Hansen I, (1985) Treatment of dairy wastewater in the developing countries-the Danish experience. India Environment 8: 2-10.

9. Demirel B, Yenigun O, Onay T T (2005) Anaerobic treatment of dairy wastewaters. Process Biochemistry. 40: 2583-2595.

10. Mavrov V, Chmiel H, Belieres E (2001) Spent process water desalination and organic removal by membranes for water reuse in the food industry. Desalination 138: 65-74.

11. Yip V, Arnsfield SD, Hydamaka AW (1996) Potential for Stainless Steel Microfiltration Processing to Reduce Effluent from a Fluid Milk and Ice Cream Processing Plant. Journal of Dairy Science 79: 710-716.

12. Blanchard BD (1991) Plant effluents dairy waste streams recovery. Dairy, Food and Environmental Sanitation 11: 494-496.

13. Koyuncu I, Turan M, Topacik D, Ates A (2000) Application of low pressure nanofiltration membranes for the recovery and reuse of dairy industry effluents. Water Science and Technology 41: 213-221.

14. Jelen P (1991) Pressure-driven membrane processes: principles and definitions. Int Dairy Fed Brussels Belgium.

15. Cowan JAC, MacTavish F, Brouckaert CJ, Jacobs EP (1992) Membrane treatment strategies for red meat abattoir effluents. Water Science and Technology 25: 137-148. 